\title{
What are Wilderness Areas for? Tourism and Political Ecologies of Wilderness Uses and Management in the Anthropocene
}

\section{Introduction}

In the contemporary global imaginary wilderness environments are considered to represent the last existing fragments of untrammeled 'real' nature, untouched by human systems and societies. As a manifestation of this the International Union for Conserving Nature (IUCN) has labelled the 'highest' protection area Category $1 \mathrm{~b}$ as 'wilderness' (Strict Nature Reserves, as a comparison, are labelled Category 1a). Such areas are considered to be large unmodified or slightly modified areas, retaining their natural character without permanent or significant human habitation. Indeed, in Western thought there is a long tradition of perceiving wilderness as a space external, and in opposition, to people, culture and civilization (see Nash, 1967; Short, 1991; Tuan, 1974). In this sense, then, wilderness becomes an emblematic anthropocenic space - one that people endeavor to define, create and maintain as removed and distinct from anthropogenic spaces - this speaks to the complex politics involved in the culturally constructed separation of people and nature, and in its reckoning in contemporary situations.

However, the existence of any firm borderline between an organized society and wilderness (as a non-human and 'unorganized' environment) has become increasingly unclear and problematic. Following the era of industrialization, wilderness areas have become heavily utilized in modern economic development projects and programs, leading to a growing and cumulative human presence in environments previously considered as 'wild' and 'pristine'. For some this increasing anthropogenic influence and/or presence in (former) natural systems has progressed to a state in which humans are now one of the 'great forces of/in nature' (Morton, 2012; see Robbins \& Moore, 2013). In current environmental discourses this increasing and visible domination by humans is said to represent the Anthropocene (Latour, 2015), the new geological epoch in which human activity has become the dominant force and influence on climate and the environment, in general (Rockström \& Klum, 2012). In addition, the idea of Anthropocene has also emerged as an epistemic system influencing practices and imaginaries that increasingly govern contemporary environmental management, which issues this paper focuses on the Finnish wilderness area context.

The idea of the Anthropocene was coined and popularized in the early 2000 by the Nobel laureate Paul Crutzen (see Crutzen, 2002; Crutzen \& Stoermer, 2000) and since that time the concept has 
come in to popular use (Brondizio et al., 2016) but also critically debated, especially in the social sciences and humanities (see Lorimer, 2012; Robbins \& Moore, 2013; Veland \& Lynch, 2016). The concept of the Anthropocene is used as an indication of global change and environmental crisis and the Earth's limits to growth (Rockström et al., 2009). It is seen as "a result of population growth and resource use, humans are now a geological force in and of themselves, driving planetary change at an unprecedented rate" (Moore, 2015, p. 32). As an idea it firmly connects global to local: due to the global processes linked with the Anthropocene, distant wilderness environments are perceived to have disappeared or they are increasingly fragmented and, thus, threatened and unable support the integrity of 'wild' ecosystems. Indeed, the Anthropocene is characterized by powerful global imaginaries of threats and disasters operating in global-local nexus which are estimated to have very serious consequences not only to the natural environment but also to human civilization and even the future existence of humans (Crutzen, 2002). Here, the question is not whether the Anthropocene is a geological fact and an epoch that follows the Holocene with the estimated consequences to humans and to the planet. Instead, the Anthropocene can be interpreted as a powerful global imagination and a social fact, although strongly dominated by natural science arguments and logics (see Castree, 2014, 2015; 2017), that is at present a prominent discourse influencing policy discussions and related practices, including environmental and conservation management issues.

As a result of these increased human impacts and pressures on the natural environment since the $19^{\text {th }}$ century many of the planet's remaining wild environments have been converted into administrative units in conservation and protected area networks (see Hendee, Stankey \& Lucas, 1990; Hovik, Sandström, \& Zachrisson, 2010; Nash, 1967) that are "managed so as to preserve their natural condition" (IUCN, 2013). Instead of existing external to 'us', however, these protected wilderness spaces are integral parts of organized societies characterized by various governance structures, laws and nationally and internationally defined management procedures (Saarinen, 2016). While legally protected, however, wilderness areas are still considered endangered due to multiple processes linked to the Anthropocene. In addition to the impacts of global warming on biodiversity and certain species of flora and fauna, in general, various localized human activities are also seen to be increasingly 'filtering in' to protected areas (see Duffy, 2015; Hall, 1992). In this respect organized commercial tourism is regarded as one of the major threats and activities that utilizes wilderness and other natural areas (Buckley, 1999; Duffy, 2002). For example, Higham (1998, p. 27) has argued that "wilderness areas are arguably the most sensitive physical resources for tourism". 
However, although contemporarily growing forms of nature-based tourism pose a potential threat to wilderness areas, there is a long symbiotic relationship between tourism and conservation (see Bukowski, 1977; Frost \& Hall, 2010). From a political ecology perspective this relationship has often led to an uneven development by marginalizing local and indigenous communities and their traditional livelihoods in the use of natural resources (see Mostafanezhad, Norum, Shelton, \& Thompson-Carr et al., 2016; Nepal \& Saarinen, 2016). In current neoliberal governance of conservation areas, tourism is increasingly used for the commodification of nature by turning intrinsic or local use values into exchange values for the purposes of non-local touristic consumption (Büscher, 2013; Duffy, 2002, 2015). The exchange value built into tourism production and consumption systems provides a rhetoric and tool to create socio-economic importance for wildernesses and, thus, a promise for local and regional development (see Büscher \& Dressler, 2012). Interestingly, in recent discussions the growing and geographically evolving tourism industry has been noticeably connected to the processes of Anthropocene: as indicated by Gren and Huijbens (2014, p. 6) tourism has become "a geophysical force censoriously interrelated with the capacity of the Earth to sustain the human species" (see also Hall \& Saarinen, 2011).

Indeed, tourism is a global activity with a substantial capacity to change the environment, particularly in the destination regions. According to Buckley (1999, p. 191) the emerging trend of commercial tourism "is important for wilderness management, because tourism is a large and powerful industry with considerable political power”. Congruently Büscher (2013, p. 57) has labelled tourism as a "Holy Grail" that holds a magical power to integrate remote conservation areas to global capitalistic markets. All this makes it challenging for wilderness managers to cope with changing use pressures and to limit or control the tourism industry, especially in the peripheral regions (where most wilderness areas are typically located) which offer limited alternative economic development options besides tourism (Butler \& Boyd, 2000; Saarinen, 2007, 2013a). Specifically, the different forms of fast growing commercial adventure tourism rely on wilderness environments, conditions and related images (see Buckley, 2006; Duffy, 2002).

Based on these multi-scalar threats, it seems that wildernesses are doomed with boundaries that are too porous or weak for them to cope with human induced invasion, activities and pollutants operating in global and local scales. This distinction, imagined opposition and 'fencing' between civilization and wilderness (Nash, 1967), however, is based on a certain kind of understanding of what nature is and what it should be. In contrast to this opposition perspective, most wilderness areas can be seen as having been part of human-environment interaction (i.e. human systems) for a 
long time; they have been influenced and modified by such relations, but still remain something we generally refer to as 'wild' (see Dahlberg, Rohde, \& Sandell, 2010; Hall, 1992; Sæpórsdóttir, Hall, \& Saarinen, 2011). Clearly, in historical or pre-industrial times the human induced changes were not global in scale, but localized human-wilderness interactions have defined wildernesses in placespecific ways: wilderness is constitutively a cultural idea. While the Western notion of wilderness as a place where "man himself is a visitor who doesn't remain" (Public Law, 1964, p. 1) represents the current global hegemonic conservation thinking, the so-called fortress model (Spinage, 1998), it does not necessarily relate consistently with all local realities, traditional meanings and use values of 'the wild' (see Bertolas, 1998; Neumann, 1998; Saarinen, 2016; Watson, Matt, Knotek, Williams, \& Yung, 2011). This underscores the previous notion that wildernesses are not indisputably outside of societies and in many places these traditional uses and ideas of wilderness are still evident and active, although often marginalized and/or under a constant heated discussion and need for justification (Connor, 2014). It also draws attention to the notion that the ways in which the Anthropocene is understood, imagined and instrumentalised is and should be very much dependent on local contextual (e.g. social, cultural, political) factors.

Interestingly, the idea of Anthropocene is seen as challenging the principle duality between society and wilderness or culture and nature. As noted by Lorimer (2012, p. 593) "the modern understanding of Nature as a pure, singular and stable domain removed from and defined in relation to urban, industrial society (...) has been central to western environmental thought and practice." For him the Anthropocene discourse represents a firm challenge to such thinking and the modern politics of nature or wilderness as distant from us. In this respect, and as I suggested above, the idea of the Anthropocene can empower us to see that there has never been a nature without us (see Mann, 2005; Castree, 2012). Therefore, and as I will argue in this paper, the idea of an apolitical and acultural wilderness may have reached an impasse. Indeed, for some there has never been a symbolic or physical fence between culture and nature. In this respect, a political ecology perspective raises interesting questions about how relatively recent localized socio-ecological threats associated with the idea of Anthropocene, such as the evolving global tourism industry, relate to other existing human-nature interactions in the wilderness environments. Basically, are changing and growing tourism activities and traditional uses of wilderness areas seen and represented differently or pooled together in wilderness management thinking and, thus, seen as common threats to biodiversity and pristine characteristics of the wild? Do these different uses collide and exclude each other? Are they valued and governed differently? In addressing these 
questions, this paper seeks to contribute to the ongoing governance and management discussions of wilderness areas in the current context of environmental change and touristic uses of the wild.

Through an empirical analysis of the management of 12 wilderness areas legally established in Finnish Lapland in 1991, this paper aims to discuss how wilderness environments and their roles are seen in the context of new and traditional anthropogenic uses and meanings of wilderness areas. These new uses and meanings refer to evolving commercial tourism based on global imaginaries of the wild which is termed here as an adventurescape that serves for various evolving touristic activities in natural settings. These activities are increasingly linked to the above described discourse of the Anthropocene on a local scale. Here, traditional views refer to indigenous and other local uses of wilderness areas, namely reindeer herding and subsistence hunting, which have been practiced for a long time in these places and well before the establishment of the present-day wilderness area network that exists in northern Finland. However, the focus of this paper is not new or traditional uses of wilderness, or their characteristics or volumes and related material struggles per se, but rather how Finnish wilderness area managers (WAMs) perceive what Finland's designated wilderness areas are for and, equally as telling, what they are not for.

These are typical questions for a political ecology approach involving processes of exclusion, inclusion and conflict in natural resource management, as well as how nature - wilderness - is valued, perceived and controlled (see Blaikie \& Brookfield, 1987; Mostafanezhad et al., 2016; Peet, Robbins \& Watts, 2011; Saarinen \& Nepal, 2016). As an approach, rather than a theoretical perspective (Robbins, 2012, p. 5), political ecology provides fruitful lens and avenues to analyze and understand how different uses and meanings of wilderness are framed and practiced in natural resource management and what kind of potential power issues and discourses are evident (Dahlberget al., 2010; Douglas, 2014; Wall-Reinius, 2012). Specifically, in this paper I use a discursive political ecology (see Bryant, 2000; Bryant \& Bailey, 1996) to evaluate the uses and management priorities and frameworks in the Finnish wilderness system. I do so by offering an analysis of how WAMs perceive wilderness and its role in the context of traditional uses, emerging tourism and, eventually, in the global biodiversity conservation agenda.

\section{"Through the Wilderness": Wilderness as a cultural and contested idea}


In the early 1980s American singer Madonna recorded a popular song 'Like a Virgin' in which she used a metaphor 'through the wilderness'. The rhetoric links the title phrase of the song and the idea of wilderness as a pristine and untouched object. This connection is based on the very context from which the song originates: western - and specifically an American - culture. In his seminal book 'Wilderness and the American Mind', Roderick Nash (1967, p. 1-2) indicates that the English term wilderness is composed of two root words ('wild' and 'deor') to denote a place inhabited by wild beasts which is beyond human influence and control (see Short, 1991, p. 6). For Nash, the wilderness received it meanings by being located outside a culture and society in the AngloAmerican context. However, at the same time, Nash (1967) underlines that wilderness is also a culturally defined concept, created by a civilization encountering and conquering the wild and constantly fencing it out. Similarly, Cronon (1995) has emphasized that wilderness is ultimately a social construction, while for Tuan (1972, p. 112) wilderness is "a state of mind" as, he argues, it is impossible to define a wilderness in an objective manner.

It is easy to agree with these philosophical views, underlining the culturally and socially defined nature of wilderness. However, they do not necessarily lead us far on a path to what wilderness environments are (or what they mean) for governance and management. In this respect, probably the most well known and influential technical definition of the wilderness originates from the world's first wilderness legislation, prescribed in the United States in 1964. According to the US Wilderness Act (Public Law 1964, p. 1):

"A wilderness, in contrast with those areas where man and his own works dominate the landscape, is hereby recognized as an area where the earth and its community of life are untrammeled by man, where man himself is a visitor who does not remain."

The core idea of the Act is based on the historically constructed Anglo-American view on wild nature and conservation of natural and pristine areas (Shields, 1991; Short, 1991). For example, the designation of Yellowstone National Park in 1872, representing the world's first large-scale unit aiming to conserve wilderness environments, was influenced by increasing anthropogenic impacts on nature in frontier lands. Specifically, it aimed to reserve and withdraw the area "from settlement, occupancy, or sale" (Nash 1967, p. 108), with a further emphasis on public use in tourism and recreation. 
Indeed, in North America, the increasing, progressive encountering and disappearing of wilderness resulted in the need to protect any and all remaining wild places. Although this process was originally situated in North America, the resulting fortress model fencing both ideologically and practically 'wild in and humans out' became a benchmark for global conservation. Currently it represents the hegemonic conservation train of thought in wilderness management globally (see Hendee, Stankey, \& Lucas, 1990; Spinage 1998). It involves a level of "anthrophobia" in conservation thinking in which "recovery, restrain, and control are imperative" (Robbins \& Moore, 2012, p. 8). This conserved wilderness functions as a 'biodiversity container' with minimizing or strictly limiting human presence and impacts (Saarinen, 2005). In contrast to indigenous and other local cultures it challenges the traditional (non-extractive) economic and cultural uses and meanings of wilderness (see Hall, 1992; Hallikainen, 1998). In Finland, for example, wilderness ('erämaa') historically signified an area outside permanent settlement but which had a crucial economic importance in terms of hunting and fishing (Lehtinen, 1991), fashioning these areas into integral parts of the human system and organized society, including elements such as taxation (Hallikainen, 1998; Saarinen, 1998). This kind of traditional wilderness was and still is an economic resource and subject of usage. In spite (or perhaps in part because) of its somewhat 'relic nature' in a modernized society, the traditional wilderness idea has remained and is manifested in the aims of the Finnish Wilderness Act (Erämaalaki, 1991). According to the Act, designated wilderness areas are founded for: (1) maintaining the wilderness character of the areas; (2) securing Sámi (indigenous) culture and related traditional livelihoods; and (3) developing a versatile use of nature and possibilities for (economic) uses. Apart from the first target, the other goals clearly refer to wilderness that is a resource inside culture and economy, and which receives its meanings mainly through its local traditional uses, roles and values.

Despite these major differences, both conserved and traditional wilderness ideas situate those environments as integral parts of contemporary societies and their institutional structures in the globalised world (Saarinen, 2005). In addition, in recent decades the tourism industry has placed an increasing interest on nature-based tourism products creating new kinds of ideas and use needs for the remaining wilderness environments, such as adventure tourism activities and organized snowmobile and sledge dog safaris (see Cloke \& Perkins, 2002; Vail \& Heldt, 2004). According to Hall and Page (1999, p. 236) a growing demand for wilderness experiences in tourism is a result of the changed and more positive attitudes towards the environment which have come about since the $19^{\text {th }}$ century. Indeed, as noted the symbiotic link between protected wild areas and tourism can be seen as old as the history of protected areas (Hall, 1992; Frost \& Hall, 2010), but recently the scale 
and nature of contemporary global scale tourism industry to utilize and impact wilderness environments is dramatically different than before (see Buckley, 1999; Fennell, 1999). The better access to natural areas has also integrated wilderness areas more closely to global and national tourism markets.

New touristic impacts and meanings are not only directly physical or based on site use alone, since the tourism industry and its marketing and commodification processes also construct certain kinds of images of wild places (see Bryant, 2000), which may in turn affect the practices related to wilderness use and management, for example (Budowski, 1977; Puhakka \& Saarinen, 2013; Rutherford, 2011). Thus, this touristic wilderness is constructed through direct and indirect impacts based on consumption, marketing and visualising natural environments and staging wilderness settings for touristic purposes, creating and using global imaginaries of wildernesses as commercialised wild spaces where a consumer is a visitor who doesn't remain (Saarinen, 2005). Indeed, nowadays wild natural environments are "universally regarded as a source of pleasure" (Wang, 2000, p. 80), a certain type of adventurescape where the tourism industry has become a significant user, stakeholder and element of change and power (Buckley, 2007; Butler \& Boyd, 2000; Saethorsdóttir, 2010). Thus, by defining wilderness as a specific site for tourist activities to take place there is a danger to marginalize other uses and meanings of wilderness. As noted by Wall-Reinius (2012, p. 622) "the idea of wilderness as pristine and empty nature [for tourist consumption and/or conservation] can have negative implications for people living in or using these areas as they become silenced and ignored" (see also Reimerson, 2016; Saarinen, 2013b; Wilson, 1999).

\section{Wilderness Area Governance and Managers' Perceptions}

\section{Finnish Wilderness Areas: Governance and Management}

While, as may be inferred from what I have presented above, it is difficult to find a consistent or fixed definition for the idea of wilderness - particularly across different national and cultural contexts - several attempts have been made to do so in laws and in connection with various agreements to establish wilderness areas. In Finland, the Wilderness Committee (Erämaakomitean mietintö, 1988, p. 23) preparing the Wilderness Law (1991) defined the basic characteristics of wilderness areas as follows: 
"1. A wilderness area should comprise a minimum of 15,000 hectares and usually be more than 10 $\mathrm{km}$ in width.

2. The area should be ecologically as diverse as possible... and all human action should be adjusted to nature so as not to spoil the wilderness character of the area.

3. The area should as a rule have no roads.

4. The landscape should be in a natural state condition and unspoiled. Any structures connected with human activity should merge with the natural landscape."

This initial framework was relatively consistent with the global hegemonic idea of conserved wilderness. Due to conflicts and compromising political process in establishing the area network, however, the resulting Wilderness Law visibly emphasized the traditional and also new versatile use possibilities of the wilderness areas in the final legal text as referred to earlier. Thus, the Law does not conflict with every person's rights (i.e. common access to nature), for example, in Finland or previous economic and culturally defined activities, such as reindeer herding, in these areas. Based on the Law, 12 designated wilderness areas (total size 14,903 sq.km) were established in northern Finnish Lapland (Figure 1). A notable governance-related issue in the Wilderness Law is that it is separated from the legal framework of nature conservation areas. Simply put, legally wilderness areas are not conservation areas, i.e. they are not separated from the surrounding spaces by the Nature Conservation Law but based on the Wilderness Act which allows human elements and versatile uses. These areas are managed by the state enterprise Metsähallitus (Parks \& Wildlife Finland, a department funded by a public budget) which initially prepared a management and land use plan for each site.

\section{ADD FIGURE 1 ABOUT HERE}

Figure 1. Location of Finnish Wilderness Area network in Lapland, Northern Finland (Authors map)

In its recently revised management plans, the Metsähallitus has utilized the Akwé: Kon Guidelines in its general management and land use plans (see Juntunen \& Stolt, 2013). These voluntary guidelines are derived from Article 8(j) of the United Nations Convention on Biological Diversity (1992). For the Metsähallitus, as the administering authority, a rationality to utilize the guidelines are based on a need "to further improve on securing the opportunities of Europe's only indigenous 
people to influence the conditions for practicing their culture in the area" (Väisänen, 2013, p. 7). According to the Director of Natural Heritage Services, Metsähallitus, the Akwé: Kon work has "significantly improved the engagement of the Sámi people in the planning process" (Väisänen, 2013, p. 7) and the model is nowadays widely implemented in various areas of Sámi homeland in Finnish Lapland. As an indigenous people forming an ethnic minority in Finland, Sweden, Norway and the Kola Peninsula of Northwest Russia, the Sámi people have their own languages, cultures, identities and histories (Aikio et al., 1994; Seurajärvi-Kari et al., 1995). Although the Sámi population does not comprise a homogeneous cultural unit, the various Sámi groups do share many common cultural and traditional features as well as economic livelihoods (see Ingold 1976; Lehtola, 2004), such as reindeer herding (although in Finland, unlike in Norway and Sweden, non-Sámi can also by law practice herding).

\section{Research Materials}

The research which follows is based on personal interviews conducted with wilderness managers (WAMs) by telephone between January and February, 2015. The WAMs are public officers employed by the Metsähallitus with a key responsibility to follow and guide the use of wilderness areas based on legal acts and existing management plans. The interviews were relatively short (app. 20-35 minutes) and structured around open-ended questions with a specific focus on potential user conflicts and related issues in wilderness thinking and management, management priorities and finally conflict management. The interviews covered all 12 wilderness areas and their responsible managers (maximum one per area), and are represented here to preserve confidentiality. Thus, although the unit of analysis is a wilderness area, any distinguishing traits of the specific area in question are not reported here. Similarly, as the number of interviewees is limited and they represent a specific and relatively easily identifiable group managing those 12 areas (and some other conservation units), the following results do not reveal any details germane to specific informants. Therefore, no identity/identifying information is used, nor are any concrete numerical references to the level of manager opinions and perceptions, since some of the issues raised may be considered delicate by the informants and/or stakeholders. In cases in which all or most of the informants share the same view, expressions such as 'majority' or 'clear majority' are used. In principle, this leaves room for individual WAMs to be considered as not sharing a given mentioned opinion, preference or argument. 
Based on the following results there are no noticeable differences between the informants and their personal information, such as gender and age, but obviously slightly different management issues, conflicts and challenges do exist across different wilderness areas. Still, because the focus of the interviews was based more on the principal level opinions and perceptions concerning the rationale and priorities in wilderness management and related use and management issues and challenges, particular differences and details of specific wilderness areas are not in the scope of this article. Secondary materials (e.g. legal documents) were used in the analysis only if the interviewees specifically referred to such sources in their argumentation.

\section{Manager views: What Wilderness Areas are for}

Based on the interviews conducted, a clear majority of the WAMs identified conflicting elements between traditional Sámi livelihoods, namely reindeer herding, and tourism. Specifically, new emerging organized forms of nature-based tourism in wilderness, such as snowmobiling and dog sledges, and related development and infrastructure needs were seen to be problematic. The issues raised were mainly focused on the negative feedback from the reindeer herders and disturbance that tourism was said to be causing for the animals and the herding practices. In addition, tourism activities were seen as influencing and limiting the (free) movement of reindeer to winter pastures critical for their condition and survival during a long cold snow period. This issue has also been noted in previous rangeland research (Helle \& Särkelä, 1992; see Akujärvi et al., 2014). There were, furthermore, issues raised with respect to occurrences outside the wilderness areas, such as increased reindeer road-kills due to seasonally intensive tourism traffic, but were potentially linked to the growing touristic use of the wild. However, although growing the visitation numbers in wilderness areas were estimated to be relatively low compared with national parks, which have better accessibility and infrastructures. However, due to common and open access (i.e. no entry fees or official entry points), there is no statistical ground for these estimates. Still, the number of naturebased tourism companies in wilderness areas were known to be growing as the businesses need a permit to operate in the areas.

Another management conflict also related to reindeer herding. Almost half of the WAMs mentioned the issue of over-grazing and resulting environmental degradation in wilderness areas, which is a widely debated issue in Finland and other Nordic counties having reindeer herding activities in protected areas (see Akujärvi et al., 2014; Benjaminsen, Reinert, Sjaadtad, \& Sara, 2015; Johnsen, Benjamisen, \& Eira, 2015). While it was perceived to be a problem, the issue was also seen as being 
under control and manageable: "Better range use planning will reduce the problems in future" (Interviewed WAM). The over-grazing issue was also linked to tourism as the existing and evolving tourist activities were partly seen as causing a lack of pasture rotation and congestion of reindeer to certain places (see Helle \& Särkelä, 1992;). While some WAMs noted that the number of reindeer may be too large for the current pastures, a clear majority of them understood the economic pressures behind the issue of maintaining the high numbers of reindeer: modern herding with various equipment and motorized vehicles, such as snowmobiles, ATVs (all-terrain vehicles) and even helicopters, is compelling the reindeer owners to have a maximum amount of animals. At the same time state subsidies have been reduced and the price the herders receive from selling reindeer meat has not increased at the same pace as petrol and other related operational costs. Thus, an increasingly market-driven economy in the utilization of wilderness areas is not serving the reindeer herders but is potentially serving tourist operations.

In respect the research aims the key interview issue for the WAMs was the question: what are the wilderness areas for? And more specifically, what is or are their priorities in the management of wilderness areas? While the question focusing on what the areas are for was introduced by the researcher, the (hierarchical) priority aspect was initiated by the interviewees during discussions. Although the term Anthropocene was not used in the interview questions, a rationale behind the questions was to learn how changing and intensifying human presence and impacts were understood and seen in relation to different uses of the wilderness areas, i.e. how localized notions of the Anthropocene are imagined and operationalised by the WAMs.

The indication of management priorities was unproblematic for the WAMs to express: a very clear majority referred to the Wilderness Act (Erämaalaki, 1991) and the need to safeguard Sámi culture and related livelihoods. In addition to the Wilderness Act, the WAMs supported their priority preference by mentioning the Metsähallitus Act (from 2004), which they considered not only giving a mandate but rather a demand that the Metsähallitus and, thus, the wilderness area management takes the indigenous people and their socio-cultural needs and values seriously. Indeed, the recently revised Metsähallitus Act (2016) states that:

"The use and protection of natural resources managed by the Metsähallitus must be reconciled in the Sámi Homeland as referred to in the Sámi Law (974/1995), in order to safeguard the conditions for practicing the Sámi culture and in the way that the obligations of reindeer herding law will be fulfilled." 
In addition to the strong need to safeguard indigenous culture and conditions for practicing such culture - namely reindeer herding - some of the WAMs mentioned that small-scale tourism is suitable for the wilderness areas. Thus, small-scale tourism operations were also supported in management decisions and practices so long as they were not in conflict with the core priority. Basically, this 'small scale' referred to individual and/or unorganized recreational tourism modes, such as hiking, that were practiced in the areas before they were designated as wilderness areas.

The support for tourism was also based on the Wilderness Act (Erämaalaki, 1991) by the WAMs and its specific aim to develop versatile use of nature and possibilities for its economic uses. That legal frame was interpreted to refer to small-scale, unorganized activities. In cases where there was to be organized tourism, the WAMs expressed a specific emphasis on 'community-based' operations, i.e. locally driven, small-scale (sustainable) tourism development. According to the WAMs this would also require official agreements between the Metsähallitus and an operator, based on the 'principles of sustainable tourism' (see Metsähallitus, 2017a), which provide an administrative tool for the management to guide touristic activities.

\section{What about Conserved Wilderness?}

There was no clearly emphasized priority towards nature conservation expressed by the interviewed WAMs. However, they may well take conservation as a granted target and, thus, have no need to consider its justification in wilderness management. This probably relates to the hegemonic conservation thinking in which the other potential uses of nature are evaluated based on how they can support or conflict with conservation goals. Still, this silence about conservation in priority discussions is somewhat surprising as the conservation element is also included in the above mentioned legal acts: the same legal frameworks provided major support for Sámi culture and related practices in wilderness, and on a limited scale to small-scale tourism development as well.

It seems that the WAMs perceive wilderness areas as locally embedded natural resource management and land-use planning units. This may represent 'a necessity as virtue' thinking: the management institution is legally obligated to provide support for the Sámi and their cultural uses and practices of the wild. In addition, the Metsähallitus needs to be open to versatile uses of nature in the wilderness areas. Interestingly, in some designated wilderness areas, such versatile uses even include forestry activities, but as the WAMs interviewed stated, the Metsähallitus took the internal 
decision to stop logging many years ago. This internal decision indicates that conservation thinking and related priorities do indeed exist, although they were latent in the interviews. Still, there were emphasized conflicts related to wilderness characteristics: for example, some of the WAMs expressed challenges between reindeer herding and the natural 'pristine' conditions of wilderness areas.

However, as noted these challenges were considered to be manageable (i.e. tolerable) in the current governance context. Indeed, due to the legal frameworks of the wilderness areas and their management there is not much the Metsähallitus can actually do in terms of limiting the cultural and related economic uses of the wild. In contrast to this, the case with evolving and transforming tourism and its impacts on wilderness and wilderness uses is a different one. The legal framework provides support for activities such as tourism. There is also major pressure for supporting tourism development in Finnish Lapland. In the regional economy, the tourism industry is a major actor and it provides more employment than any other sector utilizing natural resources in Lapland, including forestry and mining (see Regional Council of Lapland, 2015, 2016). In addition, in the peripheral parts of the province, where the wilderness areas are located, there are no substantial alternatives for tourism. Thus, the regional developers and local politicians see and promote the industry and related investments as a last resort for creating development that contributes to the regional economy and employment in local communities.

All this creates pressures for the WAMs to consider different kinds of tourism development initiatives. The general governance model of the wilderness areas also frames them as 'more open' for socio-economic needs and uses: unlike national parks the legal wilderness areas are not conservation areas and, thus, more strict conservation law cannot be used as a key guiding argument in the management priorities and decisions. As noted, however, the WAMs were not highly supportive of tourism development, especially not for non-locally driven organized and commercialised forms of nature-based and adventure tourism. In Lapland these forms include activities such as snowmobile and dog-sledge safaris which have grown considerably in the last two decades (Regional Council of Lapland, 2016; Tyrväinen et al., 2014). These forms of commercial tourism did not really exist in wilderness areas that existed when the Act was set in 1991, and they are the very same activities that the reindeer owners often regard as disturbing to their herding practices and pasture use. 
The WAMs resolve this existing (or potential future) wilderness use conflict between reindeer herding and changing forms of organized tourism in a convenient way by positioning themselves as facilitators of stakeholder relations. These conflicting uses and meanings of the wilderness are positioned as external to management; in other words, the Metsähallitus is not part of the conflict and problem but rather a solution to these that aims to deliver all the necessary targets based on their legal obligations. Sámi culture and Sámi cultural practices in the wilderness are clearly prioritized by the WAMs which is a logical outcome in the current governance context of the wilderness areas. First, contrasting a general notion of 'versatile use of nature' the cultural needs and uses are explicitly mentioned in the legal frameworks and obligations with a specific reference to Sámi Law from 1995, thus, they need to be specifically safeguarded. Secondly, this minimizes the use pressures and impacts of tourism representing a new force in the wilderness use with unknown future impacts and risks.

\section{Conclusions: Political Ecologies of Wilderness Management}

"Wilderness areas are large, uninhabited, road less and almost pristine natural areas. They are meant to be maintained as such. Therefore, only traditional livelihoods such as hunting, fishing and reindeer husbandry are possible.” (Metsähallitus, 2017b)

There is nothing apolitical in wilderness, particularly in wilderness management. Different ideas of the wild have an influence on and are guided by different priorities, meanings, understandings, uses and values of wildernesses. These meanings and use priorities are not static, nor are they historically or spatially unconditional. In traditional societies the role and uses of wilderness environments may not have been problematic for local people (Nash 1967) but, due to modernization and the recent scale of globalization and anthropogenic impacts, the uses and meanings of wilderness have become a contested landscape of various interests characterized by power relations and concomitant inclusions and exclusions.

This is particularly evident in the Finnish Wilderness Area management case in which the interviewed WAMs prioritized traditional cultural uses over evolving organized commercial forms of tourism. This distinction and hierarchy between different understandings of what wilderness areas are for was anchored in the legal governance frameworks of wilderness management in the country. These emphasized practices and meanings refer to the traditional idea of wilderness as a local economic resource and an integral part of socio-ecological systems of everyday life. For a 
long time this traditional wilderness thinking has constituted the hegemonic view of wilderness environments and their utilization in the peripheral parts of the country, especially in the northern and eastern regions of Finland. In these parts of the country even national parks, which have been established under nature conservation law, are open for various local uses, including hunting by local people. In the context of wilderness areas, the small-scale recreational tourism emphasized by the WAMs also has connections to traditional wilderness thinking: hiking as an activity involves historical links to fishing and hunting practices in Finland (see Hallikainen, 1998). In addition, both elements - the cultural practices of the Sámi and other local people, and individual hiking activities - existed in the areas prior to 1991 when they were designated to become part of the legal wilderness area network.

For these traditional uses wilderness is a place with specific cultural identities and socio-spatial characteristics. In contrast to this, commercialized and organized forms of tourism can be seen differently. For tourism wilderness is often an empty space (see Edwards, 1996; Wels, 2004) where various activities can take place, and where tourists are clearly visitors who do not remain (Saarinen, 2005). From the WAMs' perspective these activities are new and represent initiatives or influences that are 'global', i.e. something driven and initiated non-locally. Thus, they are also potentially beyond local control. Indeed, the tourism industry is increasingly seen as a global force with a capacity to effect significant impacts on the environment (see Gössling \& Hall, 2006; Higham, 1998; Stonich, 1998). This massive capacity of commercial tourism is deeply embedded in imaginaries of the Anthropocene and its localized impacts for wilderness environments and identities. It can also lend us insights into how people involved in the tourism industry and its landuse strategies and practices conceive of the role that tourism might be able to play in the Anthropocene. Based on current discourses in the tourism sector, this self-awareness in which the industry becomes conscious of itself as a planetary force is unclear, not least as UNWTO (2016, p. 10) celebrates the recent achievement in global tourist numbers: 'One Billion Tourists, One Billion Opportunities'. In relation to the sustainable tourism and use of natural resources, however, 'opportunities for whom' is a critical question.

Global imaginaries of the wild in touristic production and consumption are based on and reproduce images of pristine and untrammeled nature. The potential impacts of these kinds of images and organized tourism are difficult to demonstrate and analyze, but they are quite likely challenging for wilderness area management as they can be gradually evolving, indirect but still profound. This assumed high capacity of the tourism industry is based on structural power relations (see Harvey, 
1996) between different stakeholders across a local-global nexus. A dominance by the tourism industry, supported by neoliberal conservation emphasis (Büscher \& Dressler, 2012), can lead symbolically and practically to an exclusion of culture and people - often people other than tourists(!) - from nature and its utilization (see Neumann, 1998; Wall-Reinius, 2012). In this respect, a common characteristic of colonial depictions of distant natural places and wildernesses has been based on the descriptions of wildernesses as 'no man's land' or as an 'Eden' (see Mann, 2005). These kinds of depictions are still widely used in the touristic representations of 'exotic' destinations, for example (see Edwards, 1996; Gibson, 2010; Saarinen \& Niskala, 2009;), where natural landscapes are marketed without people present, or if there are people they are most likely 'fellow tourists' admiring a view or doing specific tourist activities (e.g. quad biking, white-water rafting, mountain biking, four-wheel driving, snowmobiling, sledge dog rides) in the wild. In the Finnish context the sledge dog safaris, for example, are culturally out of place. The activity effectively evolved with the emergence of French winter season tourism to Finnish Lapland in the late 1980s; in this context the Arctic receives meanings and images from French historical and cultural connections with (present-day) Canada, where dogs have been traditionally used for transportation. But this has not been the case in the Finnish Arctic, where tourist resorts located next to wilderness areas and reindeer pastures nowadays often have hundreds of huskies on hand, ready to serve visiting tourists.

Commodified wilderness can exclude local resource uses and indigenous communities, and include other stakeholders and activities in local and regional development (see Ramutsindela, 2007), resulting in unwanted inequalities and exclusions/inclusions in development (see Mowforth \& Munt, 1998) in order to meet what is considered as 'the wild' in the West. However, the key point of this paper has not been to focus on whether the indicated priorities and practiced inclusions and exclusions in wilderness management are 'good or bad'. This is obviously an ideological question in which the answer partly depends on the specific wilderness idea and selected stakeholder view. Taking a political ecology perspective, however, the purpose was rather to discuss, understand and demonstrate that there are different ideas and discourses of wilderness (see Bryant, 2000) which do not abide by the globally hegemonic fortress model alone. As I have aimed to show, these distinct ideas of what wilderness is and what it is for guide and structure the uses, meanings and values of natural resources as well as their control, management mechanism and conflicts in various ways (see Robbins, 2012). This involves a struggle for power, in principle, where some images and ways of using the wilderness succeed in the political process of denoting meanings better than others (Saarinen, 1998, 2005). Despite the different, often competitive and contradictory ideas and related 
uses of wilderness, there exists an understanding - a discourse - that is, in a certain moment of time and socio-spatial context, a more dominant way of thinking and acting than others.

In the current Finnish context, the traditional wilderness idea is the hegemonic discourse serving the needs of the indigenous people and locally defined and valued uses. This is not a conflict-free situation, but in respect to academic critical notions on the domination of neoliberal conservation with integral links to transnational tourism industry the emphasis on traditional and cultural uses in wilderness areas is an unexpected finding. And due to the present governance structures of Finnish Wilderness Areas it is difficult to envision that the situation would dramatically change in the near future. Interestingly, local traditional uses have been recently 'reintroduced' to some wilderness environments elsewhere. For example, in Krüger National Park (South Africa) established in 1892 based on the fortress model 'fencing people out', local communities have been allowed to engage in seasonal natural resource harvesting (see Ramutsindela, 2014). But more importantly than individual cases, with their historically contingent issues and challenges (see Ramutsindela, 2002), there has also been structural-level transformations towards more socially sustainable and inclusive governance models in global wilderness conservation thinking. IUCN, for example, has recently renewed its management guidelines for wilderness protected areas, strongly acknowledging partnerships and local and indigenous values and uses of these areas (Casson et al., 2016, see also Jamal \& Stronza, 2009; Reimerson, 2016). This is also what is intended by the Metsähallitus with the utilization of Akwé: Kon Guidelines (United Nations Convention on Biological Diversity, 1992) in Wilderness Area and National Park management in Sámi homelands. Although the hegemonic conserved wilderness idea influencing the management of a global network of areas is still largely based on a nature-culture/people distinction, these are promising initiatives and signs of alternative and changing governance models acknowledging the cultural and political nature of wilderness and their management.

Obviously, a universal wilderness governance model may not be realistic nor desirable as sociocultural, political and ecological conditions vary. This calls for further research that would focus on the contextual and place specific discourses and (also material) formations of wilderness values, socio-ecological situations and uses. The Finnish wilderness governance context may be highly specific, and commonalities even with the neighboring Nordic countries may be limited (see Hovik, Sandström \& Zachrassion, 2010; Johnsen, et al., 2015; Wall-Reinius, 2012). Therefore, international comparative and context sensitive studies would be valuable to conduct in future. In addition, there are clearly issues and conflicts between wilderness management and local views and 
uses in the Finnish context too, which would probably be much more evident and problematic were they to be approached from the local - not the management - perspective. For example, the government's unwillingness to ratify the International Labor Organization's Convention on Indigenous and Tribal Peoples (No. 169), specifically the Articles 13-19 regarding rights to land (ILO, 1989), is highly disturbing for the Sámi and creates a ground for distrust, disagreements and conflicts in land use planning in and outside the wilderness areas of the Sámi Homelands.

Thus, there is a critical need for local and indigenous perspectives on the wilderness values and management (see Watson et al., 2011). The role of growing tourism "as the key driver of neoliberalism" (Duffy, 2015, p. 529; see also Bryant, 2000; Mosedale, 2011) in the changing management ideals and practices of wilderness areas would also require more nuanced research. Local communities are not homogenous concerning their views and needs in wilderness governance, and the same complexity most probably applies to the tourism industry having different kinds of business orientations and modes. Thus, in order to fully understand the use needs, values, priorities and discourses linked to wilderness environments and their governance, a plurality of perspectives and scales in research is needed. To sum up, in future research and governance discourses it is important to evaluate critically the ways in which wildernesses and their use priorities are argued and justified from different perspectives amidst the constantly transforming contexts of natural resource management and tourism.

\section{References}

Aikio, S., Aikio, Puoskari, U., \& Helander, J. (1994). The Sámi Culture in Finland. Helsinki: Lapin Sivistysseura.

Akujärvi A., Hallikainen V., Hyppönen M., Mattila E., Mikkola K., \& Rautio P. (2014). Effects of reindeer grazing and forestry on ground lichens in Finnish Lapland. Silva Fennica, 48(3), 1-18.

Benjaminsen, T.A., Reinert, H., Sjaastad, E., \& Sara, M.N. (2015). Misreading the Arctic landscape: A political ecology of reindeer, carrying capacities, and overstocking in Finnmark, Norway. Norwegian Journal of Geography, 69(4), 219-229. 
Bertolas, R.J. (1998). Cross-cultural environmental perception of wilderness. Professional Geographer, 50(1), 98-111.

Blaikie, P., \& Brookfield, H. (1987). Land degradation and society. London: Methuen.

Brondizio, E. O’Brien, K., Bai, X., Biermann, F. Steffen, W., Berkhout, F., ... \& Chen, C-T.A. (2016). Re-conceptualizing the Anthropocene: A call for collaboration. Global Environmental Change, 39, 318-327

Bryant, R.L. (2000). Politicized moral geographies: Dabating biodiversity conservation and ancestral domain in the Philippines. Political Geography, 19, 673-705.

Bryant, R.L., \& Bailey, S. (1997). Third World political ecology. London: Routledge.

Buckley, R. (1999). Wilderness in Australia. In S. McCool, D. Cole, B. Borrie \& O’Loughlin, J. (Eds.), Wilderness Science in a Time of Change Conference, Volume 2 (pp. 190-193). Odgen: Department of Agriculture, Forest Service, Rocky Mountain Research Station.

Buckley, R. (2006). Adventure tourism. Oxfordshire: CABI.

Buckley, R. (2007). Adventure tourism products: Price, duration, size, skill, remoteness. Tourism Management, 28, 1428-1433.

Budowski, G. (1977). Tourism and conservation: conflict, coexistence, or symbiosis. Parks, 3-7.

Büscher, B. (2013). Transforming the frontier: Peace parks and the politics of neoliberal conservation in southern Africa. Durham and London: Duke University Press.

Büscher, B., \& Dressler, W. (2012). Commodity Conservation. The restructuring of community conservation in South Africa and the Philippines. Geoforum, 43, 367-376.

Butler, R., \& Boyd, S. (Eds.)(2000). Tourism and National Parks: Issues and implications. Chichester: Wiley. 
Casson, S.A., Martin V.G., Watson, A., Stringer, A., \& Kormos, C.F. (Eds.)(2016). Wilderness Protected Areas: Management guidelines for IUCN Category 1 p protected areas. Gland: IUCN.

Castree N. (2012). Making Sense of Nature. London: Routledge.

Castree, N. (2014). The Anthropocene and Geography I: The Back Story. Geography Compass, $8(7), 436-449$.

Castree, N. (2015). Geography and Global Change Science: Relationships Necessary, Absent, and Possible. Geographical Research, 53(1), 1-15.

Castree, N. (2017). Unfree Radicals: Geoscientists, the Anthropocene, and Left Politics. Antipode, $49(1), 52-74$.

Cloke, P., \& Perkins, H. (2002). Commodification and Adventure in New Zealand. Current Issues in Tourism, 5(6), 521-549.

Connor, T. (2014). Conserved spaces, ancestral places. Pietermaritzburg: University of KwaZuluNatal Press.

Convention on Biological Diversity (1992). United Nations: New York.

(https://www.cbd.int/doc/legal/cbd-en.pdf)

Cronon, W. (1998). The Trouble with Wilderness, or Getting Back to the Wrong Nature. In J.

Callicott \& M. Nelson (Eds.), The Great New Wilderness Debate (pp. 471-499). Athens, GA:

University of Georgia Press.

Crutzen, P.J. (2002). Geology of mankind. Nature 415, 23.

Crutzen, P.J., \& Stoermer, E.F. (2000). The Anthropocene. Global Change Newsletter, 41, 17-18. 
Dahlberg, A., Rohde, R., \& Sandell, K. (2010). National parks and environmental justice:

Comparing access rights and ideological legacies in three countries. Conservation and Society, 8(3), 209-224.

Douglas, J. A. (2014). What's political ecology got to do with tourism? Tourism Geographies, 16, $8-13$.

Duffy, R. (2002). A trip too far: ecotourism, politics and exploitation. London: Earthscan.

Duffy, R. (2015). Nature-based tourism and neoliberalism: concealing contradictions. Tourism Geographies, 17, 529-543.

Edwards, A. (1996). Postcards - Greetings from Another World. In T. Selwyn (Ed.), The Tourist Image: Myths and Myth Making in Tourism (pp. 198-221). Chichester: Wiley.

Erämaalaki (1991). Suomen säädöskokoelma [Finnish Act Collection] no. 62, 129-131.

Erämaakomitean mietintö (1988). Komiteamietintö [Committee report] 1988:39. Helsinki: Valtion painatuskeskus.

Fennell, D. (1999). Ecotourism: an introduction. New York, NY: Routledge.

Frost, W., \& Hall, C.M. (Eds.)(2010). Tourism and national parks. London: Routledge.

Forsyth, T. (2008). Political ecology and the epistemology of social justice. Geoforum, 39, 756764.

Gibson C. (2010). Geographies of tourism: (un)ethical encounters. Progress in Human Geography, 34, 521-527.

Gren, M., \& Huijbens, E. (2014). Tourism and the Anthropocene. Scandinavian Journal of Hospitality and Tourism, 14(1), 6-22. 
Gössling, S., \& Hall, C.M. (Eds.)(2006). Tourism and Global Environmental Change. London: Routledge.

Hall, C.M. (1992). Wasteland to World Heritage: Preserving Australia's Wilderness. Melbourne: Melbourne University Press.

Hall, C.M. (1994). Tourism and politics: policy, power and place. Chichester: Wiley.

Hall, C.M, \& Page, S. (2002). The geography of tourism: Environment, place and space. London: Routledge.

Hall, C.M., \& Saarinen, J. (2010). Geotourism and Climate Change: Paradoxes and Promises of Geotourism in Polar Regions. Téoros, 29(2), 77-86

Hallikainen, V. (1998). The Finnish wilderness experience. Metsäntutkimuslaitoksen tiedonantoja, $711,1-288$.

Harvey, D. (1996). Justice, nature, and the geography of difference. Oxford, UK: Blackwell.,

Helle, T., \& Särkelä, M. (1992). The effects of outdoor recreation on range use by semidomesticated reindeer. Scandinavian Journal of Forest Research, 8(1-4), 123-133.

Hendee, J., G. Stankey, \& Lucas, P. (1990). Wilderness management. Golden, CO: Fulcrum.

Higham, J. (1998). Sustaining the physical and social dimensions of wilderness tourism: the perceptual approach to wilderness management in New Zealand. Journal of Sustainable Tourism, $6(1), 26-51$.

Hovik, S., Sandström, C., \& Zachrassion, A. (2010). Management of protected areas in Norway and Sweden: Challenges in combining central governance and local participation. Journal of Environmental Policy \& Planning, 12, 159-177,

ILO (International Labour Organization) (1989). Indigenous and tribal peoples convention No. 169. Geneve: General Conference of the International Labour Office. 
Ingold, T. (1976). The Skolt Lapps Today. Cambridge, UK: Cambridge University Press.

IUCN (2013). IUCN Protected Areas Categories System.

(http://www.iucn.org/about/work/programmes/gpap_home/gpap_quality/gpap_pacategories/)

Jamal, T. \& Stronza, A. (2009). Collaboration theory and tourism practice in protected areas:

Stakeholders, structuring and sustainability. Journal of Sustainable Tourism, 17, 169-189.

Johnsen, K.I., Benjamisen, T.A., \& Eira, I.M.G (2015). Seeing like the state or like pastoralists?

Conflicting narratives on the governance of Sámi reindeer husbandry in Finnmark, Norway.

Norwegian Journal of Geography, 69(4), 230-241.

Juntunen, S., \& Stolt, E. (2013). Application of Akwé: Kon Guidelines in the Management and Land Use Plan for the Hammastunturi Wilderness Area. Helsinki: Metsähallitus.

Latour, B. (2015). Telling friends from foes in the time of the Anthropocene. In C. Hamilton, F. Gemenne \& C. Bonneuil (Eds.), The Anthropocene and the global environmental crisis: Rethinking modernity in a new epoch (pp. 145-155). Abingdon: Routledge.

Lehtinen, A. (1991). Northern natures: a study of the forest question emerging within the timberline conflict in Finland. Fennia, 169, 57-169.

Lehtola, V. (2004). The Sámi people: Traditions in transition. Inari: Kustannus-Puntsi.

Lorimer, J. (2012). Multinatural geographies for the Anthropocene. Progress in Human Geography, $36,593-612$.

Lu, J., \& Nepal, S.K. (2009). Sustainable tourism research: an analysis of papers published in the Journal of Sustainable Tourism. Journal of Sustainable Tourism, 17, 5-16,

Mann, C. (2005). 1491: New Revelations of the Americas Before Columbus. New York, NY:

Knopf. 
Metsähallitus (2017a). Principles of sustainable tourism

(http://www.metsa.fi/web/en/sustainablenaturetourism)

Metsähallitus (2017b). Lapin erämaa-alueet - kauas kaikesta [Lapland wilderness areas - faraway from everything]. (http://www.luontoon.fi/eramaa-alueet)

Metsähallitus Act (2016). Act on Metsähallitus (234/2016).

Moore, A. (2015). Tourism in the Anthropocene Park? New analytic possibilities. International Journal of Tourism Anthropology, 4(2), 186-200.

Morton, T. (2012). From modernity to the Anthropocene: ecology and art in the age of asymmetry. International Social Science Journal, 63(207-208), 39-51.

Mosedale, J. (Ed.)(2011). Political economy of tourism. Abingdon: Routledge.

Mostafanezhad, M., Norum, R., Shelton, E. J., \& Thompson-Carr, A. (Eds.)(2016). Political Ecology of Tourism: Community, Power and the Environment. London: Routledge.

Mowforth, M., \& Munt, I. (1998). Tourism and sustainability: a new tourism in the Third World. London and New York, NY: Routledge.

Nash, R. (1967). Wilderness and the American Mind. London: Yale University Press.

Nepal, J., \& Saarinen, J. (Eds.)(2016). Political Ecology and Tourism. London, Routledge.

Neumann, R. (1998). Imposing Wilderness: Struggles over Livelihood and Nature Preservation in Africa. Berkley, CA: University of California Press.

Peet, R. Robbins, P., \& Watts, M.J. (Eds.)(2011). Global political ecology. London: Routledge.

Public Law (1964). Public Law 88-577. 88th Congress, September 3, 1964. 
Puhakka, R., \& J. Saarinen (2013). New role of tourism in national park planning in Finland. Journal of Environment and Development, 22(4), 412-435.

Ramutsindela, M. (2002). The perfect way to ending a painful past? Makuleke land deal in South Africa. Geoforum, 33, 15-24.

Ramutsindela, M. (2007). Transfrontier Conservation in Africa: At the Confluence of Capital, Politics and Nature. Wallingford: CABI.

Ramutsidela, M. (Ed.)(2014). Cartographies of Nature: How Nature Conservation Animates Borders. New Castle upon Tyne: Cambridge Scholars Publishing.

Regional Council of Lapland (2015). Lapin matkailustrategia [Lapland tourism strategy] 20152018.

(http://www.lappi.fi/lapinliitto/c/document library/get file?folderId=2265071\&name=DLFE25498.pdf

Regional Council of Lapland (2016). Lapin matkailutilastot [Tourism statistics in Lapland] 2016. ( http://www.lappi.fi/lapinliitto/julkaisut ja tilastot/matkailu)

Reimerson, E. (2016). Sámi space for agency in the management of the Laponia World Heritage Site. Local Environment, 21(7), 808-826.

Robbins, P. (2012). Political ecology: A critical introduction. Malden, MA: Wiley-Blackwell.

Robbins, P., \& Moore, S. A. (2013). Ecological anxiety disorder: Diagnosing the politics of the Anthropocene. Cultural Geographies, 20(1), 3-19.

Rockström, J., \& Klum, M. (2012). The human quest-Prospering within planetary boundaries. Stockholm: Bokförlaget Langenskiöld.

Rockström, J., Steffen, W., Noone, K., Persson, Å., Stuart Chapin III, F., Lambin, E.F., ... \& Foley, J.A. (2009). A safe operating space for humanity. Nature, 461, 472-475. 
Rutherford, S. (2011). Governing the Wild: Ecotours of Power. Minneapolis, MN: University of Minnesota Press.

Saarinen, J. (1998). Wilderness, Tourism Development and Sustainability: Wilderness Attitudes and Place Ethics. In A.E. Watson \& G. Aplet (Eds.), Personal, Societal, and Ecological Values of Wilderness: Sixth World Wilderness Congress Proceedings on Research, Management, and Allocation, Vol. I (pp. 29-34). General Technical Report, Ogden, UT. USDA Forest Service, Rocky Mountain Research Station.

Saarinen, J. (2005). Tourism in Northern Wildernesses: Nature-Based Tourism Development in Northern Finland. In C.M. Hall \& S. Boyd (Eds.), Nature-based Tourism in Peripheral Areas: Development or Disaster (pp. 36-49)? Clevedon: Channelview Publications.

Saarinen, J. (2007). Tourism in peripheries: the role of tourism in regional development in Northern Finland. In B. Jansson \& D. Muller (Eds.), Tourism in High Latitude Peripheries: Space, Place, and Environment (pp. 41-52). Oxon: CABI.

Saarinen, J. (2013a). 'Tourism into the wild': The limits of tourism in wilderness. In A. Holden \& D. Fennell (Eds.), The Routledge Handbook of Tourism and the Environment (pp. 145-154). London, Routledge.

Saarinen, J. (2013b). Indigenous tourism and the challenge of sustainability. In M. Smith \& G. Richards (Eds.), Routledge Handbook of Cultural Tourism (pp. 220-226). London: Routledge.

Saarinen, J. (2016). Wilderness conservation and tourism: What do we protect for and from whom? Tourism Geographies, 18(1), 1-8.

Saarinen, J., \& Nepal, S.K. (2016). Conclusions: Towards a political ecology of tourism - key issues and research prospects. In S.K. Nepal \& J. Saarinen (Eds.), Political Ecology and Tourism (pp. 253-264). London, Routledge.

Saarinen, J., \& Niskala, M. (2009). Local culture and regional development: The role of OvaHimba in Namibian tourism. In P. Hottola (Ed.), Tourism strategies and local responses in Southern African (pp. 61-72). Wallingford: CABI Publishing. 
Seurajärvi-Kari, I., Aikio-Puoskari, U., Morottaja, M., Saressalo, L., Pentikäinen, J., \& Hirvonen, V. (1995). The Sámi People in Finland. In J. Pentikäinen \& M. Hiltunen (Eds.), Cultural minorities in Finland. An Overviev towards Cultural Policy (pp. 101-146). Helsinki: Finnish National Commission for Unesco.

Shields, R. (1991). Places on the margin: alternative geographies of modernity. London: Routledge.

Short, R. (1991). Imagined Country. London: Routledge.

Spinage, C. (1998). Social change and conservation misrepresentation in Africa. Oryx, 32(4), 265276.

Stonich S.C. (1998). Political ecology of tourism. Annals of Tourism Research, 25, 25-54.

Sæbórsdóttir, A-D. (2010). Planning nature tourism in Iceland based on tourist attitudes. Tourism Geographies, 12(1), 25-52.

Sæpórsdóttir, A-D., Hall, C.M., \& Saarinen, J. (2011). Making wilderness: Tourism and the history of the wilderness idea in Iceland. Polar Geography, 34, 249-273.

Tuan, Y-F. (1974). Topophilia. New Jersey, NJ: Prentice-Hall Inc.

Tyrväinen, L., Uusitalo, M., Silvennoinen, H., \& Hasu, E. (2014). Towards sustainable growth in nature-based tourism destinations: Clients' views of land use options in Finnish Lapland. Landscape and Urban Planning, 122, 1-15.

UNWTO (World Tourism Organization)(2016). UNWTO Annual Report 2015. UNWTO: Madrid.

Vail, D., \& Heldt, T. (2004). Governing snowmobilers in multiple-use landscapes: Swedish and Maine (USA) cases. Ecological Economics, 48, 469-483. 
Veland, S., \& Lynch, A.H. (2016). Scaling the Anthropocene: How the stories we tell matter. Geoforum, 72, 1-5.

Väisänen, R. (2013). Foreword. In S. Juntunen \& E. Stolt (Eds.), Application of Akwé: Kon Guidelines in the Management and Land Use Plan for the Hammastunturi Wilderness Area (pp. 7 8). Helsinki: Metsähallitus.

Wall-Reinius, S. (2012). Wilderness and culture: Tourist views and experiences in the Laponian World Heritage Area. Society and Natural Resources, 25, 621-632.

Wang, N. (2000). Tourism and Modernity. Amsterdam: Pergamon.

Watson, A., Matt, R., Knotek, K., Williams, D. \& Yung, L. (2011). Traditional wisdom: Protecting relationship with wilderness as a cultural landscape. Ecology and Society, 16(1),

Wels, H. (2004). About Romance and Reality: Popular European Imagery in Postcolonial Tourism in Southern Africa. In C.M. Hall \& H. Tucker (Eds.), Tourism and Postcolonialism: Contested Discourses, Identities and Representation (pp. 76-94). London: Routledge.

Wilson, R.K. (1999). 'Placing nature': the politics of collaboration and representation in the struggle for La Sierra in San Luis, Colorado. Ecumene, 6, 1-28. 